\title{
Depth Profiles of Nitrogen and Oxygen absorbed in HAZ of ZrTN802D Alloy Tube by TIG Welding in Various Atmospheres (Report 2)*
}

\author{
By Kojiro KOMURO ${ }^{* *}$, Teruaki MISHIMA***, Satoshi KUROSAWA ${ }^{* * *}$ and Hajime TSUBOI ${ }^{* * *}$
}

\begin{abstract}
As a study relative to the evaluation of corrosion characteristics in high temperature water of welds of ZrTN802D alloy (Zircaloy-2) tubes, continued investigations were made on the depth profiles of nitrogen $(N)$ and oxygen $(O)$ absorbed in HAZ by TIG welding in various atmospheres.

A calculation was attempted to estimate $N$ depth profiles in a portion heated to $\beta$ phase temperature range in HAZ. Although the calculated depth profiles were somewhat different from those of SIMS analysis values at the portions nearer the surface, the calculated value was seen to decrease rapidly toward the value of $N$ in base metal with increase of depth. It was also found out by additional chemical and SIMS analyses of $N$ after surface etching of the welds that the depth of diffusion of $N$ in $H A Z$ was not deep under this welding condition.

$O$ was absorbed and diffused in the region heated within $\alpha$ phase range in $H A Z$, and it was also confirmed that the diffusion depth was shallower.
\end{abstract}

Key words : TIG welding, $Z r$ alloy, Weld heat affected zone, Nitrogen absorption, Oxygen absorption

\section{Introduction}

With regard to tube-to-end-plug welding of ZrTN802D (Popularly called as Zircaloy-2, abbreviated herein as Zry-2) tubes, the characteristics of welds which were welded by TIG in atmospheres with various nitrogen and oxygen partial pressures $\left(\mathrm{P}_{\mathrm{N}_{2}}\right.$ and $\left.\mathrm{P}_{\mathrm{O}_{2}}\right)$ at total pressures $\left(\mathrm{P}_{\mathrm{T}}\right)$ of 0.10 and $0.32 \mathrm{MPa}$ have been investigated by same authors ${ }^{1-4)}$. Upon these investigations, it was made clear that the nitrogen $(\mathrm{N})$ and oxygen $(\mathrm{O})$ were absorbed not only in weld metal but in $\mathrm{HAZ}$ when $\mathrm{P}_{\mathrm{N}_{2}}$ and $\mathrm{P}_{\mathrm{O}_{2}}$ increased.

As the corrosion characteristic in high temperature water of welds containing $\mathrm{HAZ}$ of $\mathrm{Zr}$ alloys is affected by $\mathrm{N}$ and $\mathrm{O}$ contents therein ${ }^{5)}$, it is useful to know the depth profiles of $\mathrm{N}$ and $\mathrm{O}$ as well as their average values in welds, and the corrosion behavior thereat can be estimated from these profiles.

Therefore, the depth profiles of $\mathrm{N}$ and $\mathrm{O}$ absorbed in $\mathrm{HAZ}$ of Zry-2 tube were measured and evaluated by applying Secondary Ion Mass Spectrometry (SIMS) as related to the microstructure changes therein and the results were reported in Report $1^{6}$. By this previous report it was made clear that $\mathrm{N}$ was absorbed at the region heated to $\beta$ or $\alpha+\beta$ phase temperature range (abbreviated herein as $\beta$ phase range) in $\mathrm{HAZ}$ and diffused deep into inside when $\mathrm{P}_{\mathrm{N}_{2}}$ increased. Also $\mathrm{O}$ was absorbed more at the region heated within $\alpha$ phase range rather than $\beta$ or $\alpha+\beta$ phase range in HAZ and did not diffuse deeper even when $\mathrm{P}_{\mathrm{o}_{2}}$ increased.

Based on the results above, with special regard to the diffusion of $\mathrm{N}$ which has shown clear absorption in HAZ, a calculation was attempted to determine the depth profile from surface to deeper portion in $\mathrm{HAZ}$ of welds by TIG. Also the depth profiles of $\mathrm{N}$ and $\mathrm{O}$ in $\mathrm{HAZ}$ were investigated by an additional examination.

\section{Experimental procedure}

\subsection{Materials used for the examination}

The welding test for this study was carried out by Zry -2 tube-to-end-plug welding. The chemical composition of these materials is shown in Table 1, and the shape of test specimen is shown in Fig. 1. Zry-2 tubes were fabricated by the process of three steps cold rolling and $\alpha$ annealing using an $\alpha+\beta$ quenched tube shell $(64 \mathrm{~mm}$ $\phi$ O.D. $\times 11 \mathrm{mmt}$ ).

\subsection{Welding equipment used for the examination}

The welding equipment with an evacuation-backfill type welding chamber as shown in Report 1 was used for the examinations.

Table 1 Chemical compositions of Zry-2 tube and end plug (mass\%).

\begin{tabular}{|c|c|c|c|c|c|c|c|}
\hline Material & $\mathrm{Sn}$ & $\mathrm{Fe}$ & $\mathrm{Cr}$ & $\mathrm{Ni}$ & 0 & $\mathrm{~N}$ & $\mathrm{Zr}$ \\
\hline Tube & 1.29 & 0.18 & 0.10 & 0.07 & 0.116 & 0.0032 & $\mathrm{BaI}$ \\
\hline End plug & 1.30 & 0.19 & 0.09 & 0.07 & 0.105 & 0.0031 & $\mathrm{Bal}$ \\
\hline
\end{tabular}

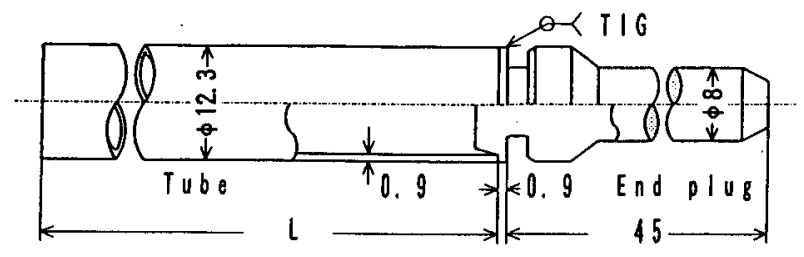

Fig. 1 Shape and size of tube-to-end-plug weld test specimen.

\footnotetext{
* Received: 11 January 1995.

** Member, J.N.F. Service Engineering Co., Ltd.

*** Member, Japan Nuclear Fuel Co., Ltd.
} 


\subsection{Welding-test gases}

In this investigation, $\mathrm{He}$ and $\mathrm{Ar}$ gases containing a small quantity of impurities $\left(\mathrm{N}_{2}=1 \mathrm{vol}\right.$.ppm, $\mathrm{O}_{2}=4 \mathrm{vol}$. ppm) and containing various quantities of $\mathrm{N}_{2}$ ( $\leqq 160 \mathrm{vol}$. ppm) and $\mathrm{O}_{2}$ ( $\leqq 40$ vol.ppm) as shown in Table 2 were used as welding-test gases.

\subsection{Welding method and welding condition}

The tube-to-end-plug welding for this investigation was carried out in the following manner.

A $\mathrm{Zry}-2$ tube and an end plug were set at the welding chamber, and after the chamber and inside of the tube were evacuated to $6.5 \times 10^{-6} \mathrm{MPa}$ and filled with the welding-test gas, the end plug was seated into the tube end. The gas overflowed to outside of chamber and the pressure in weld chamber (abbreviated herein as $\mathrm{P}_{\mathrm{T}}$ ) was held at 0.10 and $0.32 \mathrm{MPa}$ during welding by means of a pressure regulator. Under above conditions, welding was performed rotating the tube and end plug synchronously.

Table 3 shows the welding condition. In the case of $\mathrm{P}_{\mathrm{T}}=0.10 \mathrm{MPa}$, mixed gas with 80 vol. $\%$ of $\mathrm{He}$ and 20 vol. $\%$ of Ar was used to have easier arc starting and to maintain enough deep penetration. On the other hand, in the case of $\mathrm{P}_{\mathrm{T}}=0.32 \mathrm{MPa}$, only $\mathrm{He}$ gas was used to meet specification for the seal welding of the nuclear fuel rod. The tube-to-end-plug welding was performed by two passes without filler metal.

\subsection{Surface etching}

The welds were etched by $10-40 \mu \mathrm{m}$ of their surface in

Table 2 Contents of $\mathrm{O}_{2}, \mathrm{~N}_{2}$ and other impurities in welding-test-gases (vol.ppm).

\begin{tabular}{|c|c|c|c|c|c|c|c|}
\hline Gas & Group & $\mathrm{O}_{2}$ & $\mathrm{~N}_{2}$ & $\mathrm{H}_{2}$ & $\mathrm{CH}_{1}$ & $\mathrm{CO}$ & $\mathrm{CO}_{2}$ \\
\hline \multirow{4}{*}{$\mathrm{He}$} & 1 & 1 & 4 & $\leq 0.5$ & $\leq 0.1$ & $\leq 0.1$ & $\leq 0.1$ \\
\cline { 2 - 8 } & 2 & 40 & 4 & $\leq 0.5$ & $\leq 0.1$ & $\leq 0.1$ & $\leq 0.1$ \\
\cline { 2 - 8 } & 3 & $10 \sim 40$ & $40 \sim 160$ & $\leq 0.5$ & $\leq 0.1$ & $\leq 0.1$ & $\leq 0.1$ \\
\hline \multirow{3}{*}{$\mathrm{Ar}$} & 1 & 1 & 4 & $\leq 1.0$ & $\leq 0.1$ & - & $\leq 0.1$ \\
\cline { 2 - 8 } & 2 & 20 & 80 & $\leq 1.0$ & $\leq 0.1$ & - & $\leq 0.1$ \\
\hline
\end{tabular}

Table 3 Welding condition.

\begin{tabular}{|c|c|c|}
\hline \multirow{2}{*}{ Weld parameter } & \multicolumn{2}{|c|}{ Ambient pressure ( $\mathrm{MPa}$ ) } \\
\hline & 0.10 & 0.32 \\
\hline Electrode dia. ${ }^{* 1}(\mathrm{~m} \phi)$ & 1. 0 & 1.6 \\
\hline Arc length $\quad(\mathrm{mm})$ & 0.5 & 0.5 \\
\hline Welding current ${ }^{2}(A)$ & $10 \sim 35$ & $10 \sim 28$ \\
\hline Welding speed ( $\mathrm{mm} / \mathrm{min})$ & 350 & 350 \\
\hline $\begin{array}{c}\text { Shield gas flow rate } \\
(1 / \mathrm{min})\end{array}$ & $\begin{array}{l}\text { He : } 20 \\
\text { Ar : } 5\end{array}$ & $\mathrm{He}: 25$ \\
\hline
\end{tabular}

*1:2* Th-W * * DC SP a solution of $\mathrm{HF}$ and $\mathrm{HNO}_{3}$ to evaluate the $\mathrm{N}$ contents in the surface thin layer of HAZ. Besides other welds were etched by $10-20 \mu \mathrm{m}$ of their surface in the same solution as above for SIMS analysis.

\subsection{Test method}

\subsubsection{Measurement of $N$ and $O$ ion intensity by SIMS}

The samples for SIMS analysis containing weld metal and $\mathrm{HAZ}$ as shown in Fig. 2 were prepared by machining from the welds one as welded and the others etched of the surface.

$\mathrm{Cs}^{+}$ions were irradiated on targets at $\mathrm{HAZ}$ as shown in Fig. 3 and the secondary ions, ${ }^{90} \mathrm{Zr}^{14} \mathrm{~N}^{-},{ }^{18} \mathrm{O}^{-}$and ${ }^{90} \mathrm{Zr}^{-}$ were collected and scanned by step-scanning process ${ }^{6}$.

\subsubsection{Chemical analysis on $N$ in $H A Z$}

Chemical analysis on $\mathrm{N}$ in HAZ was performed of the welds which were as welded and etched of its surface The samples for chemical analysis were prepared by machining from the region near the weld fusion line and

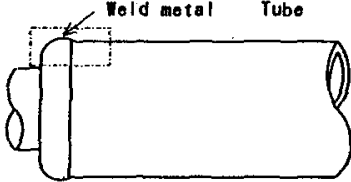

Wolded samplo

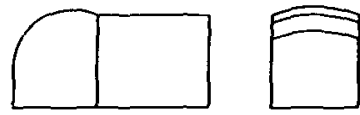

analysis sample
Fig. 2 Sampling method of specimen for SIMS analysis.

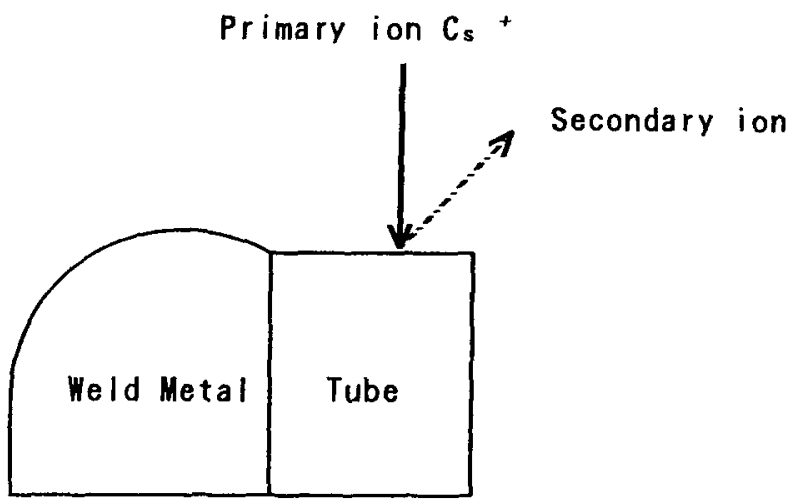

Fig. 3 Direction of $\mathrm{Cs}^{+}$ion irradiation on HAZ.

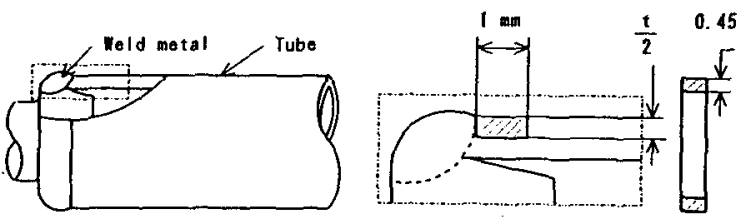

(a) As welded sample

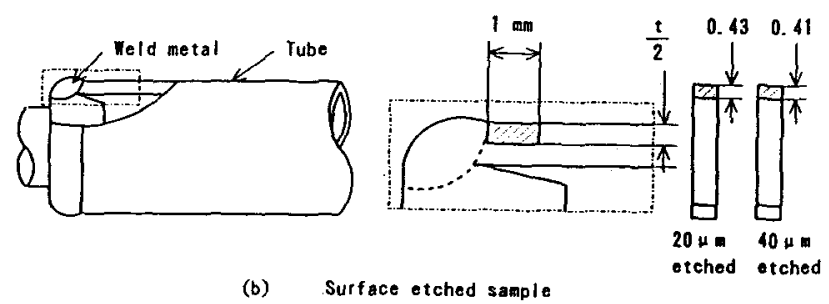

Fig. 4 Sampling method of specimen for chemical analysis at HAZ. 
outer half of wall thickness (W.T.) of tube as shown in Fig. 4. And $\mathrm{N}$ in those samples was analyzed by the inert gas melting-thermal conductivity method using LECO Type TC-436 Nitrogen and Oxygen Analyzer.

\section{Experimental results and discussion}

\section{$3.1 \quad N$ depth profile by SIMS analysis and calculation}

As reported in Report $1^{6}$, $\mathrm{N}$ was absorbed highly at the surface in $\mathrm{HAZ}$ and diffused deep into inside at the ragion heated to $\beta$ phase range $(1,250-2,113 \mathrm{~K})$ when $P_{\mathrm{N}_{2}}$ increased. Typical depth profiles of secondary ion intensity of ${ }^{90} \mathrm{Zr}^{14} \mathrm{~N}^{-}$by SIMS analysis (abbreviated herein as Ii $\left[{ }^{90} \mathrm{Zr}^{14} \mathrm{~N}\right]$, incidentally it has been confirmed that Ii $\left[{ }^{90} \mathrm{Zr}^{14} \mathrm{~N}\right]$ was equivalent to $\mathrm{N}$ content in $\mathrm{Zry}-2^{6)}$ ) are as shown in Fig. 5. This figure shows $\operatorname{Ii}\left[{ }^{90} \mathrm{Zr}^{14} \mathrm{~N}\right]$ depth profiles at the portion $\mathrm{L}=1 \mathrm{~mm}$ ( $\mathrm{L}$ : distance from fusion line, hereinafter shown as same) in $\mathrm{HAZ}$ welded in atmospheres with $\mathrm{P}_{\mathrm{N}_{2}}=8.0 \mathrm{~Pa}\left(\mathrm{P}_{\mathrm{O}_{2}}=2.1 \mathrm{~Pa}\right)$ at $\mathrm{P}_{\mathrm{T}}=$ $0.10 \mathrm{MPa}$ and $\mathrm{P}_{\mathrm{N}_{2}}=53.3 \mathrm{~Pa}\left(\mathrm{P}_{\mathrm{o}_{2}}=13.9 \mathrm{~Pa}\right)$ at $\mathrm{P}_{\mathrm{T}}=0.32$ $\mathrm{MPa}$. It also shows $\mathrm{Ii}\left[{ }^{90} \mathrm{Zr}^{14} \mathrm{~N}\right]$ depth profile at the portion $\mathrm{L}=5 \mathrm{~mm}$ in $\mathrm{HAZ}$ welded in an atmosphere with $\mathrm{P}_{\mathrm{N}_{2}}=8.0 \mathrm{~Pa} \quad\left(\mathrm{P}_{\mathrm{O}_{2}}=2.1 \mathrm{~Pa}\right)$ at $\mathrm{P}_{\mathrm{T}}=0.10 \mathrm{MPa}$. That is, Ii $\left[{ }^{90} \mathrm{Zr}^{14} \mathrm{~N}\right]$ depth profile at the portion $\mathrm{L}=5 \mathrm{~mm}$ heated within $\alpha$ phase range in $H A Z$ was flat and on the same low level as in Zry-2 base metal (also in the case of $\mathrm{P}_{\mathrm{T}}=$ $0.32 \mathrm{MPa}$, Ii $\left[{ }^{90} \mathrm{Zr}{ }^{14} \mathrm{~N}\right]$ depth profile at the portion $\mathrm{L}=5$ $\mathrm{mm}$ in $\mathrm{HAZ}$ was same as this). On the other hand, Ii $\left[{ }^{90} \mathrm{Zr}^{14} \mathrm{~N}\right]$ at the portion $\mathrm{L}=1 \mathrm{~mm}$ heated to $\beta$ phase range in $\mathrm{HAZ}$ was higher at its surface and decreased

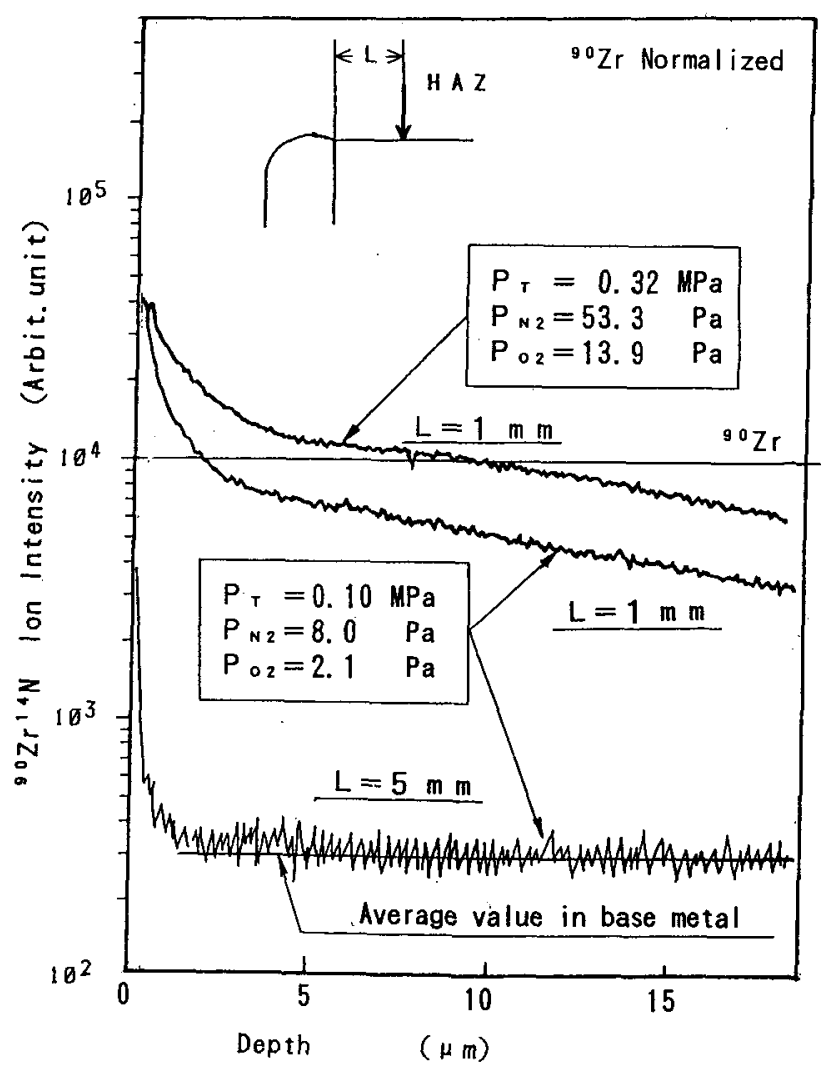

Fig.5 Typical depth profiles of ${ }^{90} \mathrm{Zr}^{14} \mathrm{~N}$ ion intensity in HAZ exponentially with increase of the depth in both cases of $\mathrm{P}_{\mathrm{T}}=0.10$ and $0.32 \mathrm{MPa}$. And even at the portion of 18 $\mu \mathrm{m}$ deep inside, which is the maximum depth of detection (in this examination, it was made available to us to continue spattering by $\mathrm{Cs}^{+}$ion irradiation for a time to reach $18 \mu \mathrm{m}$ deep inside), Ii $\left[{ }^{90} \mathrm{Zr}^{14} \mathrm{~N}\right]$ was on a higher level than that of Zry-2 base metal.

Therefore, here it was attempted to calculate the depth profiles of $\mathrm{N}$ diffused in $\mathrm{HAZ}$ containing portions still deeper than $18 \mu \mathrm{m}$ based on the SIMS analysis values.

The concentration $\mathrm{C}$ (mass ppm) of $\mathrm{N}$ at a portion of $x(\mathrm{~cm})$ in depth from surface can be calculated by the equation (1) on the assumption that (1) the diffusion of $\mathrm{N}$ in $\mathrm{Zr}$ alloy obeys the Fick's low, (2) the diffusion coefficient of $\mathrm{N}$ in $\mathrm{Zr}$ alloy does not change by concentration of $\mathrm{N}$, (3) there is no anisotropy on diffusion of $\mathrm{N}$ in $\mathrm{Zr}$ alloy and (4) concentration of $\mathrm{N}$ at the surface of $\mathrm{HAZ}$ does not change during the time heated to $\beta$ phase range $^{7-9)}$.

$$
\mathrm{C}-\mathrm{C}_{0}=\left(\mathrm{C}_{1}-\mathrm{C}_{0}\right)[1-\Phi(\mathrm{x} / 2 \sqrt{\mathrm{Dt}})]
$$

where $\mathrm{C}_{0}$ : Concentration of $\mathrm{N}$ in base metal (mass ppm), $\mathrm{C}_{1}$ : Concentration of $\mathrm{N}$ at surface (mass ppm), $\mathrm{x}$ : Depth from surface $(\mathrm{cm}), \mathrm{D}$ : Diffusion coefficient $\left(\mathrm{cm}^{2} / \mathrm{s}\right), \mathrm{t}$ : Time of diffusion $(\mathrm{s})$.

To calculate concentration $\mathrm{C}$ of $\mathrm{N}$ at a portion $\mathrm{x}(\mathrm{cm})$ in depth in HAZ by equation (1), the value of diffusion coefficient $\mathrm{D}$ and concentration $\mathrm{C}_{1}$ are needed.

The diffusion coefficient $\mathrm{D}$ was calculated as follows. As described in Report 1, the absorption and diffusion of $\mathrm{N}$ at $\mathrm{HAZ}$ in Zry-2 occurs at the $\beta$ phase. The $\mathrm{D}$ of $\beta$ phase $\mathrm{Zr}$ is given by equation $(2)^{10)}$.

$$
\mathrm{D}=1.5 \times 10^{-2} \exp -\left(\frac{30,700 \pm 1,000}{\mathrm{RT}}\right)\left(\mathrm{cm}^{2} / \mathrm{s}\right)
$$

In welding, the heating temperature at a certain portion is not constant but changes continuously in form of thermal cycle during welding. In that case, the mean value $\overline{\mathrm{Dt}}$ has been determined integrally by dividing the time by $\mathrm{n}$ equally, and the calculated diffusion depth using this mean value $\overline{\mathrm{Dt}}$ has been in good agreement with experimental diffusion depth of carbon into pure iron at a thermal cycle ${ }^{8,11}$. Although it has not been verified that the Dt determined by the same process as above was applicable or not for the calculation of diffusion of $\mathrm{N}$ into $\mathrm{Zr}$ alloy such as $Z$ ry-2, this process was taken to determine $\mathrm{D}$ assuming it was applicable in this study.

The mean value $\overline{\mathrm{Dt}}$ of diffusion coefficient during welding cycles was determined by equation (3) simulating the above process.

$$
\begin{aligned}
\overline{\mathrm{Dt}}= & \frac{1}{\mathrm{n}}\left\{\int_{\mathrm{t} 0}^{\mathrm{t} 1} \mathrm{D} 1(\mathrm{t}) \mathrm{dt}+\int_{\mathrm{t} 1}^{\mathrm{t} 2} \mathrm{D} 2(\mathrm{t}) \mathrm{dt}\right. \\
& \left.\cdots+\int_{\mathrm{t}_{\mathrm{n}-1}}^{\mathrm{t}_{\mathrm{n}}} \mathrm{Dn}(\mathrm{t}) \mathrm{dt}\right\}
\end{aligned}
$$

where $t_{0}$ : time when temperature rose to $\beta$ phase $(1,250$ 
$\mathrm{K}), t_{n}$ : time when temperature fell down to $\alpha$ phase $(1,250 \mathrm{~K}), \mathrm{t}_{1}, \mathrm{t}_{2} \cdots \mathrm{t}_{\mathrm{n}-1}$ : time divided $\mathrm{t}_{0}-\mathrm{t}_{\mathrm{n}}$.

To calculate $\overline{\mathrm{Dt}}$ by equation (2) and (3) at the portion $\mathrm{L}=1 \mathrm{~mm}$ in $\mathrm{HAZ}$ dividing the time $\mathrm{t}_{0}-\mathrm{t}_{\mathrm{n}}$ by $10 \quad(\mathrm{n}=10)$ equally, $\mathrm{D}_{\mathrm{a}}=4 \times 10^{-7} \mathrm{~cm}^{2} / \mathrm{s}\left(\mathrm{P}_{\mathrm{T}}=0.1 \mathrm{MPa}\right)$ and $\mathrm{D}_{\mathrm{b}}=2.7 \times$ $10^{-7} \mathrm{~cm}^{2} / \mathrm{s}\left(\mathrm{P}_{\mathrm{T}}=0.32 \mathrm{MPa}\right)$ were obtained. Actually in the welding of tube with $0.9 \mathrm{~mm}$ thickness as shown in Fig. 1, though the thermal cycles at the portion $L=1 \mathrm{~mm}$ in $\mathrm{HAZ}$ might not be completely same throughout the surface to back side, it was also assumed to be same in this study.

Besides, the concentration $\mathrm{C}_{1}$ of $\mathrm{N}$ at the surface of $\mathrm{HAZ}$ was estimated from the value of SIMS analysis values as follows. $\left[i\left[{ }^{90} \mathrm{Zr}^{14} \mathrm{~N}\right]\right.$ at the surface of $\mathrm{HAZ}$ is not to be read clearly from Fig. 5 , but $I i\left[{ }^{90} \mathrm{Zr}{ }^{14} \mathrm{~N}\right]$ at the portion of $\mathrm{X}=1 \mu \mathrm{m}$ ( $\mathrm{X}$ is depth from surface, hereinafter shown as same) can be read clearly. Though, the value of $\operatorname{Ii}\left[{ }^{90} \mathrm{Zr}{ }^{14} \mathrm{~N}\right]=1.43 \times 10^{4}$ (Arbit. unit, hereinafter shown as same) at the portion $\mathrm{L}=1 \mathrm{~mm}$ in $\mathrm{HAZ}$ was used as a standard value of this calculation. To convert Ii $\left[{ }^{90} \mathrm{Zr}^{14} \mathrm{~N}\right]$ into $\mathrm{N}$ concentration using an equation ${ }^{6}$, Ii $\left[{ }^{90} \mathrm{Zr}^{14} \mathrm{~N}\right]=1.43 \times 10^{4}$ is equivalent to $\mathrm{N}=1,525$ mass ppm. $\mathrm{N}$ concentration $\mathrm{C}_{1}$ at the surface was calculated in reverse by the equation (1) substituting the value of $\mathrm{N}=1,525$ mass ppm for $\mathrm{C}$ and $\mathrm{x}=1 \mu \mathrm{m}$ as follows.

$$
\begin{aligned}
\mathrm{C}_{1} & =\left\{\left(\mathrm{C}-\mathrm{C}_{0}\right) /[1-\Phi(\mathrm{x} / 2 \sqrt{\mathrm{Dt}})]\right\}+\mathrm{C}_{0} \\
& =\left\{1,493 /\left[1-\Phi\left(1 \times 10^{-4} / 2 \sqrt{4 \times 10^{-7} \times 5}\right)\right]\right\}+32 \\
& =1,571 \text { mass ppm }
\end{aligned}
$$

where the previously calculated mean value $\mathrm{D}\left(4 \times 10^{-7}\right.$ $\left.\mathrm{cm}^{2} / \mathrm{s}\right)$ and actual heating time $\mathrm{t}(5 \mathrm{sec})$ in $\beta$ phase range were used. That is, the concentration of $\mathrm{N}$ at the surface of the portion $\mathrm{L}=1 \mathrm{~mm}$ in $\mathrm{HAZ}$ in the case of $\mathrm{P}_{\mathrm{T}}=0.10 \mathrm{MPa}$ shown in Fig. 5 was estimated to be 1,571 mass ppm. $\mathrm{N}$ concentration $\mathrm{C}$ at the portion of depth $\mathrm{x}$ was calculated by equation (1) using this value as $C_{1}$, and $\mathrm{D}$ and $\mathrm{t}$ as above.

Fig. 6 shows the relation between depth from surface and $\mathrm{N}$ concentration in $\mathrm{HAZ}$ in the case of $\mathrm{P}_{\mathrm{T}}=0.10$ MPa. This figure shows $\mathrm{N}$ depth profile of converted value from $\operatorname{Ii}\left[{ }^{0} \mathrm{Zr}^{14} \mathrm{~N}\right]$ by SIMS analysis and calculated value based on the estimated value at the surface. The calculated value of $\mathrm{N}$ decreased rapidly from a high level at the surface toward the value of base metal (32 mass ppm) with increase of depth. The $\mathrm{N}$ concentrations were estimated to be 36 mass ppm at $60 \mu \mathrm{m}$ deep inside and nearly equal to the value of base metal at 75 $\mu \mathrm{m}$ deep inside.

By same calculation process as above, the concentration $\mathrm{C}_{1}$ of $\mathrm{N}$ at the surface of the portion $\mathrm{L}=1 \mathrm{~mm}$ in $\mathrm{HAZ}$ in the case of $\mathrm{P}_{\mathrm{T}}=0.32 \mathrm{MPa}$ shown in Fig. 5 was estimated to be 2,626 mass ppm. N concentration $\mathrm{C}$ at the portion of depth $\mathrm{x}$ was calculated by equation (1), using this value as $C_{1}$, the previously calculated mean value $\mathrm{D}\left(2.7 \times 10^{-7} \mathrm{~cm}^{2} / \mathrm{s}\right)$, and the actual heating time $\mathrm{t}$ $(4.5 \mathrm{sec})$ in $\beta$ phase range.

Fig. 7 shows the relation between depth from surface and $\mathrm{N}$ concentration in $\mathrm{HAZ}$ in the case of $\mathrm{P}_{\mathrm{T}}=0.32$ $\mathrm{MPa}$. The calculated value of $\mathrm{N}$ decreased more rapidly from a high level at the surface toward the value of base metal with increase of the depth. The $\mathrm{N}$ concentrations were estimated to be 36 mass ppm at $50 \mu \mathrm{m}$ deep inside and nearly equal to the value of base metal at $60 \mu \mathrm{m}$ deep inside. Although the calculated value at the surface in Fig. 7 was much higher than that of Fig. 6, it decreased more rapidly and reached a low level as base metal at shallower portions. The result must have been brought about by the fact that the $\mathrm{P}_{\mathrm{N}_{2}}$ in welding atmosphere was much higher (53.3 $\mathrm{Pa}$ ) and absorbed much $\mathrm{N}$

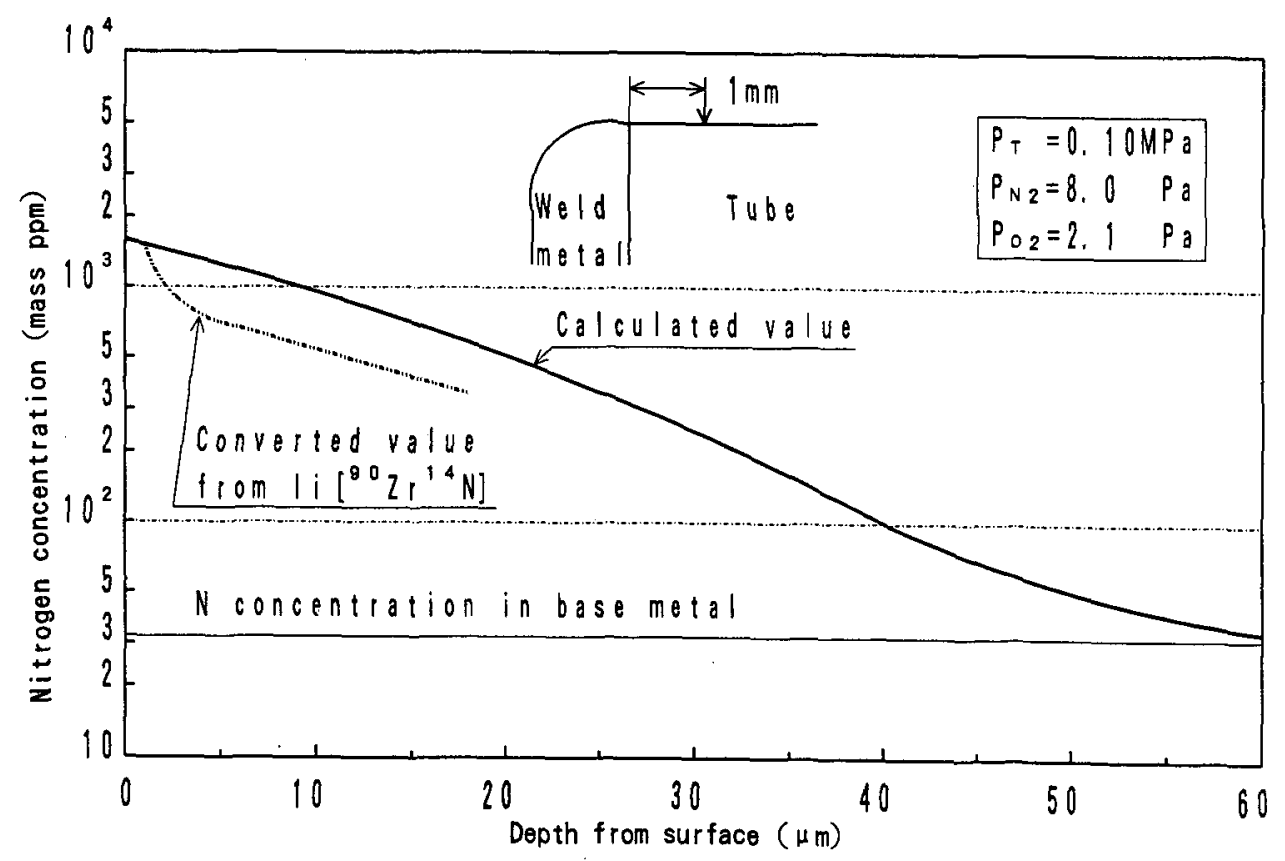

Fig. 6 Relation between depth from surface and nitrogen concentration in HAZ (1). 


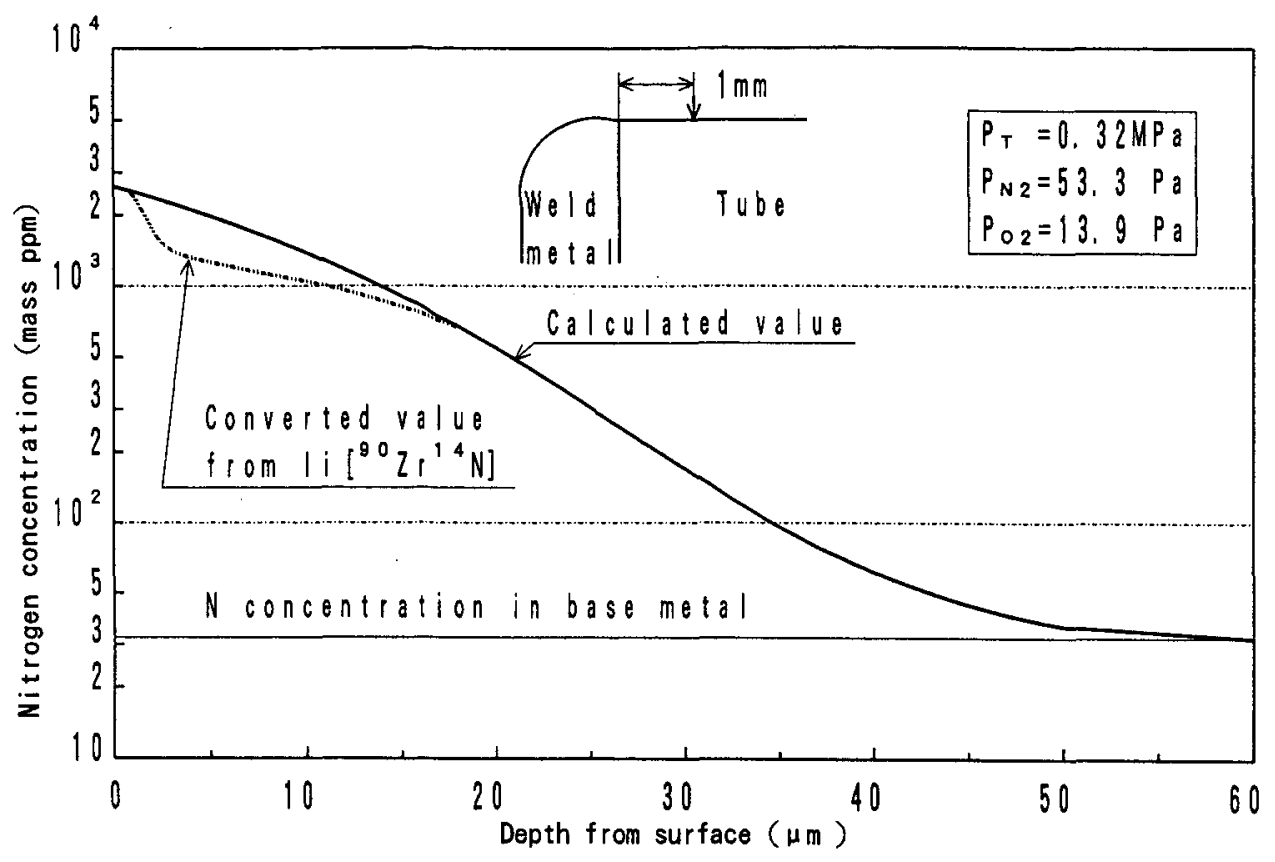

Fig. 7 Relation between depth from surface and nitrogen concentration in HAZ (2).

at near surface, while diffusion rate of $\mathrm{N}$ was lower because of their lower heating temperature and shorter heating time at the portion in $\mathrm{HAZ}$ in the case of $\mathrm{P}_{\mathrm{T}}=$ $0.32 \mathrm{MPa}$ as described in Report 1.

As the results above show, in both cases of Fig. 6 and Fig. 7 , the $\mathrm{N}$ values converted from $\operatorname{Ii}\left[{ }^{90} \mathrm{Zr}^{14} \mathrm{~N}\right]$ were lower than that of calculated values near the surface and they approached each other as the depth increases. At present, the reason why of this difference at portions near the surface is still not clear.

$3.2 N$ content in $H A Z$ before and after surface etching

To evaluate $\mathrm{N}$ depth profile in $\mathrm{HAZ}$, chemical analysis method was also applied. It was impossible to analyze $\mathrm{N}$ content directly in thin layers of $\mathrm{HAZ}$ as 10 or $20 \mu \mathrm{m}$ in thickness, because sample making of such uniform thin thickness was very difficult and the quantity of, sample was not enough for analysis, even if it could have been done by some other process. So, an alternative evaluation method, or an estimation of $\mathrm{N}$ depth profile in $\mathrm{HAZ}$ was applied, comparing the chemical analysis values of samples removed of its surface thin layers of 20 and $40 \mu \mathrm{m}$ by etching with those of as welded samples.

Fig. 8 shows the relation between etched thickness at surface and N content in HAZ (at the portion shown in Fig. 4) of welds which were welded in atmospheres with various $P_{N_{2}}$ at $P_{T}=0.32 \mathrm{MPa} . N$ in the outer half of $W$. $T$. in $H A Z$ as welded increased with the increase of $P_{N_{2}}$. After the surface were etched by 20 and $40 \mu \mathrm{m}, \mathrm{N}$ in same portion as above of HAZ decreased to a level as low as the value of $Z$ ry- 2 base metal. From the result, it was estimated that the $N$ concentration in the surface layer is particularly high and most of the absorptions of $\mathrm{N}$ in HAZ should be limited to the thin layer of near

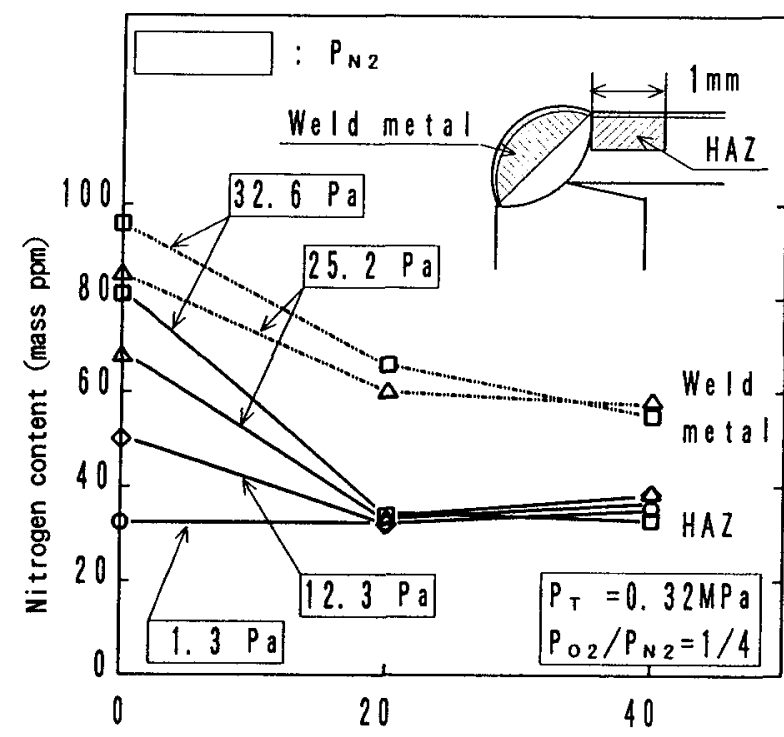

(As welded) Etched thickness at surface $(\mu \mathrm{m})$

Fig. 8 Relation between etched thickness at surface and nitrogen content in HAZ.

surface in the case of welding condition of this study.

As $\mathrm{N}$ concentration was estimated by the calculation to 550 mass ppm at $20 \mu \mathrm{m}$ deep inside and to 59 mass ppm at $40 \mu \mathrm{m}$ deep inside in the case of $\mathrm{P}_{\mathrm{N}_{2}}=53.3 \mathrm{~Pa}$ $\left(\mathrm{P}_{\mathrm{T}}=0.32 \mathrm{MPa}\right)$ as shown in Fig. 7 , a significant quantity of $\mathrm{N}$ must have diffused into 20 and $40 \mu \mathrm{m}$ deep inside even in the case of $\mathrm{P}_{\mathrm{N}_{2}}=25.2$ and $32.6 \mathrm{~Pa} \quad\left(\mathrm{P}_{\mathrm{T}}=0.32\right.$ $\mathrm{MPa})$. These effects did not appear on the analysis values for the $\mathrm{N}$ in analysis samples might have been homogenized by melting at the analysis examination.

$\mathrm{N}$ contents in outer half of weld metal removed by 20 and $40 \mu \mathrm{m}$ of surface by etching were shown comparatively in Fig. 8. In the weld metals which were welded in the atmosphere of $\mathrm{P}_{\mathrm{N}_{2}}=25.2$ and $32.6 \mathrm{~Pa} \quad\left(\mathrm{P}_{\mathrm{T}}=0.32\right.$ 


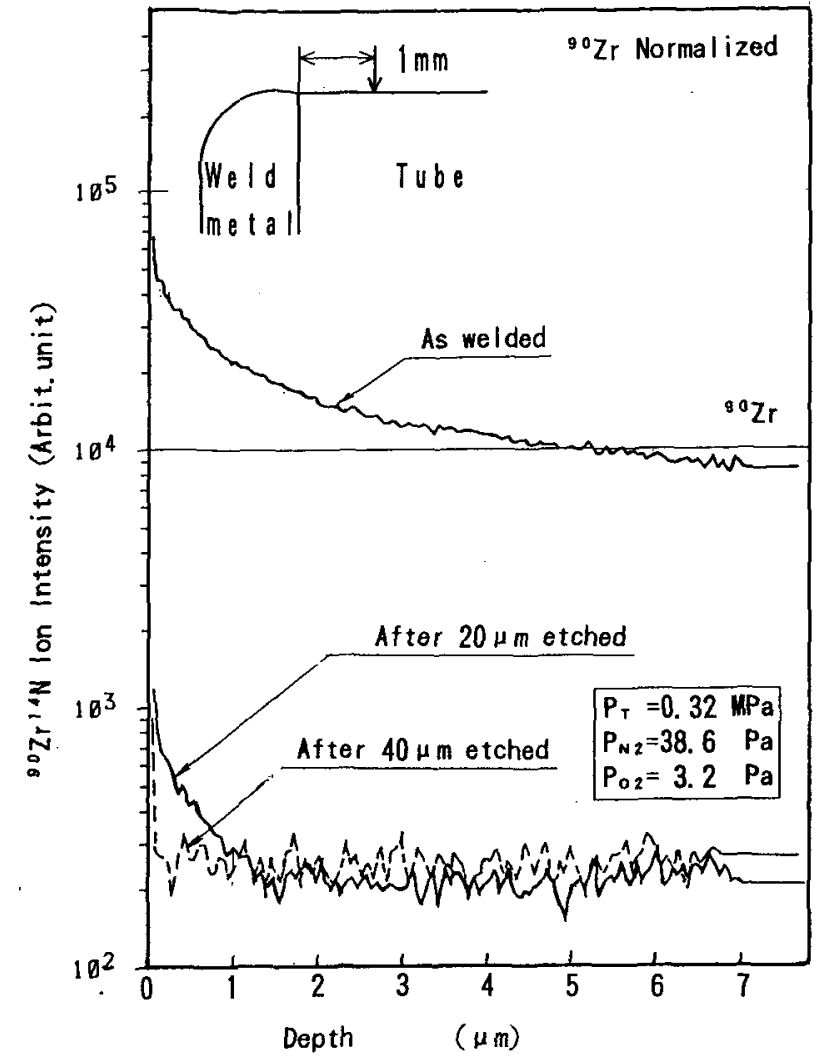

Fig. 9 Depth profiles of ${ }^{90} \mathrm{Zr}^{14} \mathrm{~N}$ ion intensity in $\mathrm{HAZ}$ after etched.

$\mathrm{MPa}$ ), $\mathrm{N}$ contents were still on a higher level than base metal even removed of its surface up to $40 \mu \mathrm{m}$. From these results it was made clear that $\mathrm{N}$ did not get into deep inside in $\mathrm{HAZ}$ which has not melted but heated just below the melting point ( $\beta$-phase range) because it was taken into only through diffusion, while $\mathrm{N}$ got into deeper inside the weld metal because it was taken into not only by diffusion but also by convection of molten metal.

\section{3 $N$ depth profile by SIMS analysis after surface etching}

Fig. 9 shows Ii $\left[{ }^{90} \mathrm{Zr}^{14} \mathrm{~N}\right]$ depth profiles at the portion $\mathrm{L}=1 \mathrm{~mm}$ in $\mathrm{HAZ}$ welded in an atmosphere with $\mathrm{P}_{\mathrm{N}_{2}}=$ $38.6 \mathrm{~Pa}\left(\mathrm{P}_{\mathrm{O}_{2}}=3.2 \mathrm{~Pa}\right)$ at $\mathrm{P}_{\mathrm{T}}=0.32 \mathrm{MPa}$ as welded and after etched of its surface by 20 and $40 \mu \mathrm{m}$. Although Ii $\left[{ }^{90} \mathrm{Zr}^{14} \mathrm{~N}\right]$ near the surface in $\mathrm{HAZ}$ as welded was on high levels same as the value shown in Fig. 5 , Ii $\left[{ }^{90} \mathrm{Zr}^{14} \mathrm{~N}\right]$ near the surface after etched by $20 \mu \mathrm{m}$ has decreased and been found on a level as low as the value of base metal at approx. $5 \mu \mathrm{m}$ in depth and deeper inside. After etched by $40 \mu \mathrm{m}$, Ii $\left[{ }^{90} \mathrm{Zr}{ }^{14} \mathrm{~N}\right]$ has decreased to a level as low as the value of base metal at its surface.

Therefore, from this results it was also made clear that the diffusion of $\mathrm{N}$ was shallow and most of $\mathrm{N}$ did not get into deeper than $40 \mu \mathrm{m}$ in $\mathrm{HAZ}$ in the case of above welding conditions.

\section{$3.4 O$ depth profile in $H A Z$}

By the investigation with regard to $O$ depth profile in $\mathrm{HAZ}$ by SIMS analysis, it has been made clear that $\mathrm{O}$

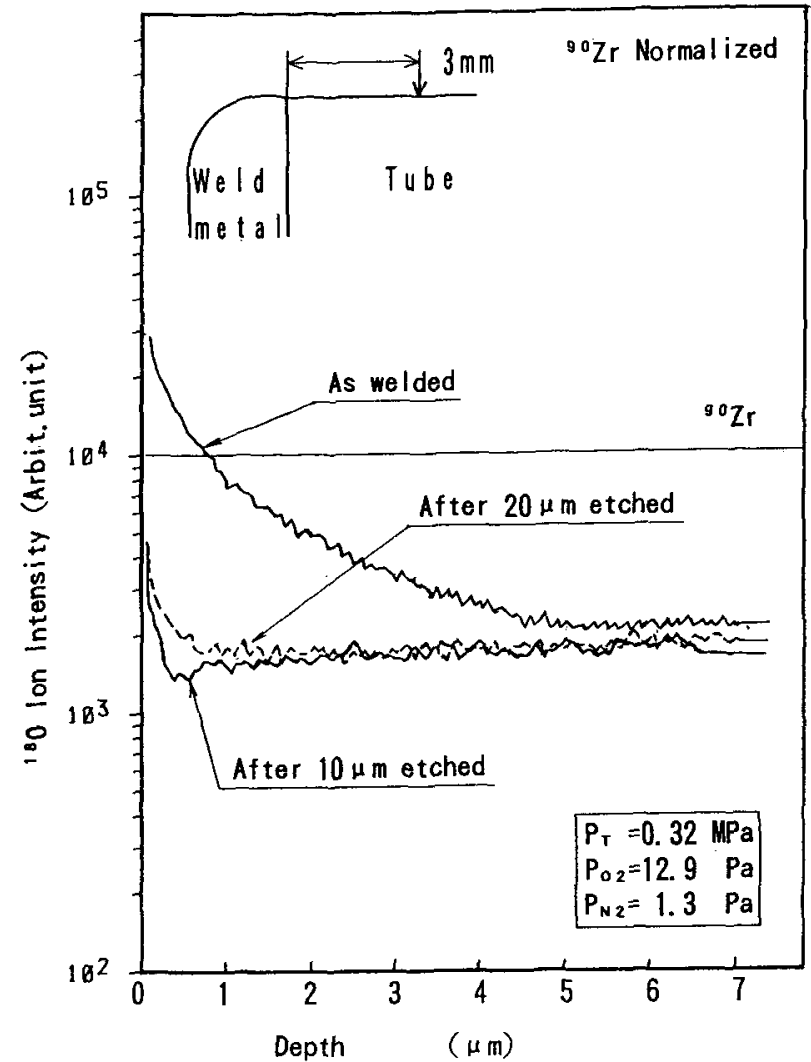

Fig. 10 Depth profiles of ${ }^{18} \mathrm{O}$ ion intensity in $\mathrm{HAZ}$ after etched.

was absorbed mostly at the portion $\mathrm{L}=3$ or $4 \mathrm{~mm}$ heated within $\alpha$ phase range rather than $L=1$ or $2 \mathrm{~mm}$ heated to $\beta$ phase range as described in Report 1 . And the diffusion depth was not as deep as with $\mathrm{N}$, and estimated to extend only approx. to $5 \mu \mathrm{m}$. Therefore, to make it clear, $O$ depth profiles were taken at the most absorbed portion in $\mathrm{HAZ}$ after etched. Fig. 10 shows $\mathrm{Ii}\left[{ }^{18} \mathrm{O}\right]$ depth profiles at the portion of $\mathrm{L}=3 \mathrm{~mm}$ in $\mathrm{HAZ}$, welded in an atmosphere of $\mathrm{P}_{\mathrm{O}_{2}}=12.9 \mathrm{~Pa}\left(\mathrm{P}_{\mathrm{N}_{2}}=1.3 \mathrm{~Pa}\right)$ at $\mathrm{Pt}=0.32$ $\mathrm{MPa}$ and after etched by 10 and $20 \mu \mathrm{m}$, comparing with as welded.

Both of the $\mathrm{Ii}\left[{ }^{18} \mathrm{O}\right]$ depth profiles were on a level as low as the value of Zry-2 base metal near the surface, and it was indicated that the depths of diffusion of $O$ thereat were not deeper than $10 \mu \mathrm{m}$, and $\mathrm{O}$ might form thin oxide layer with $\mathrm{Zr}$ in the case of comparatively low level of $\mathrm{P}_{\mathrm{O}_{2}}$ as under the welding conditions of this examination.

\section{Conclusion}

Continued inventigations were made on the depth profiles of nitrogen $(\mathrm{N})$ and oxygen $(\mathrm{O})$ absorbed in HAZ of ZrTN802D alloy (Zry-2) tubes by TIG welding in atmospheres with varied $\mathrm{N}_{2}$ and $\mathrm{O}_{2}$ partial pressures $\left(\mathrm{P}_{\mathrm{N}_{2}}\right.$ and $\left.\mathrm{P}_{\mathrm{O}_{2}}\right)$ at total pressures $\left(\mathrm{P}_{\mathrm{T}}\right)$ of 0.10 and 0.32 $\mathrm{MPa}$. The results obtained from these investigations are as follows:

(1) By the calculation of depth profile of $\mathrm{N}$ using the SIMS analytical values near the surface, it was made 
clear that high concentration of 1,571 mass ppm of $\mathrm{N}$ at the surface in $\mathrm{HAZ}$ welded under a condition of $\mathrm{P}_{\mathrm{N}_{2}}=8.0$ $\mathrm{Pa}$ and $\mathrm{P}_{\mathrm{T}}=0.10 \mathrm{MPa}$ decreased rapidly toward the value of base metal with increase of depth and reached a low level nearly equal to the value of base metal at the portion of $75 \mu \mathrm{m}$ in depth.

(2) Also high concentration of 2,626 mass ppm of $\mathrm{N}$ at the surface in $\mathrm{HAZ}$ welded under another condition of $\mathrm{P}_{\mathrm{N}_{2}}=53.3 \mathrm{~Pa}$ and $\mathrm{P}_{\mathrm{T}}=0.32 \mathrm{MPa}$ decreased more rapidly toward the value of base metal with increase of depth and reached a low level nearly equal to the value of base metal at the portion of $60 \mu \mathrm{m}$ in depth.

(3) Although there were some differences between SIMS analysis values and the calculated values at near surface, a tendency to approximate was observable of the two values as depth increased.

(4) As the N content in a part of the outside half of thickness of HAZ, after being etched of its surface by 20 and $40 \mu \mathrm{m}$, became low in level same as with base metal even the HAZ had contained 60 to 80 mass ppm of $\mathrm{N}$ as welded, it was made clear, also from this result, that $\mathrm{N}$ had diffused into only thin layers near the surface in $\mathrm{HAZ}$ under the welding conditions of this examination. (5) SIMS analysis was also made on the etched (20 and $40 \mu \mathrm{m})$ surface of HAZ of a weld which indicated a higher level of $N$ depth profile in HAZ as welded. The $\mathrm{N}$ depth profile on the etched $(40 \mu \mathrm{m}) \mathrm{HAZ}$ was almost same as the base metal and it was further made clear also from this results, that the depth of diffusion of $\mathrm{N}$ was not deep.

(6) O depth profile in HAZ after being etched each by 10 and $20 \mu \mathrm{m}$ of welds, which had indicated significantly high levels of $O$ depth profile as welded, became low in level same as with the base metal. Thus it was estimated that $\mathrm{O}$ might form thin oxide layer at surface with $\mathrm{Zr}$ and did not diffuse deeper inside in the case of comparatively low level of $\mathrm{P}_{\mathrm{O}_{2}}$ as under the welding conditions of this examination.

\section{Acknowledgement}

The authors appreciate the helpful suggestions of Professor T. Onzawa, Tokyo Institute of Technology, Professor M. Ushio and the late Professor Y. Nakao, Osaka University in proceeding this study, and would like to thank Dr. H. Tamura and Mr. H. Sumiya, Hitachi Instruments Eng. Co., Ltd, for their support on SIMS analysis.

\section{References}

1) K. Komuro et al.: TIG Welding Phenomenon and Properties of Welds in Welding Atmospheres with Various Oxygen and Nitrogen Partial Pressures (Part 1), J. of Japan Weld. Soc., 12-2 (1994), 224-228.

2) K. Komuro et al. : Depth Profile of Oxygen and Nitrogen Concentration in Weld Metals by TIG Welding, J. of Japan Weld. Soc., 12-2 (1994), 229-235.

3) K. Komuro et al.: TIG Welding Phenomenon and Properties of Welds in Welding Atmospheres with Various Oxygen and Nitrogen Partial Pressures (Part 2), J. of Japan Weld. Soc., 12-3 (1994), 386-392.

4) K. Komuro et al.: Welding Atmosphere and Properties of TIG. Weld Heat Affected Zone (Part 1), J. of Japan Weld. Soc., 12-3 (1994), 393-397.

5) L. Lunde: Special Features of External Corrosion of Fuel Cladding in Boiling Water Reactors, Nuclear Engineering and Design, 33 (1975), 178-195.

6) K. Komuro et al. : Depth Profile of Nitrogen and Oxygen absorbed in HAZ of ZrTN802D Alloy Tube by TIG Welding in Various Atmospheres (Report 1), J. of Japan Weld. Soc., 13-4 (1995), 491-499.

7) H. Suzuki et al.: Spot Welding of Zircaloy-2 Alloy Sheets, J. of Japan Weld. Soc., 30-6 (1961), 425.

8) H. Ikawa et al.: Diffusion Phenomenon of Carbon in Steel during Weld Thermal Cycles, J. of Japan Weld. Soc., 43-7 (1974), 650-660.

9) T. Naito: Actual Practices of Carbonizing Quenching, Nikkan Kogyo Shinbunsha (1979), 29.

10) B. Lustman et al.: The Metallurgy of Zirconium ; McGRAW-HILL (1955), 422.

11) Y.Kikuchi : JIW BULLETIN 13, (1994), 34-37. 